\title{
Statyba
}

\section{DEFLECTION PREDICTIONS FOR LIGHTLY REINFORCED CONCRETE BEAMS USING DIFFERENT CONSTITUTIVE RELATIONSHIPS AND METHODS}

\section{G. Kaklauskas PhD \& D. Bačinskas}

To cite this article: G. Kaklauskas PhD \& D. Bačinskas (2000) DEFLECTION PREDICTIONS FOR LIGHTLY REINFORCED CONCRETE BEAMS USING DIFFERENT CONSTITUTIVE RELATIONSHIPS AND METHODS, Statyba, 6:1, 3-10, DOI: $10.1080 / 13921525.2000 .10531557$

To link to this article: https://doi.org/10.1080/13921525.2000.10531557

Published online: 26 Jul 2012.

Submit your article to this journal $₫$

凹 Article views: 111 


\section{DEFLECTION PREDICTIONS FOR LIGHTLY REINFORCED CONCRETE BEAMS USING DIFFERENT CONSTITUTIVE RELATIONSHIPS AND METHODS}

\section{G. Kaklauskas, D. Bačinskas}

\section{Introduction}

Reinforced concrete is probably the most commonly used of all structural materials and the flexural members is the most important class of structures. As a result of the extensive research work carried out in different countries, the ultimate load behaviour of flexural members is now quite well understood. With the present trend of use of higher strength concrete and reinforcement, leading to longer spans and smaller depths, deformations are often the governing design criterion. Besides, accurate deformation estimates are needed not only for deflection cal culation, but also for more accurate estimates of load carrying capacity of some structures. An adequate modelling of concrete cracking and, particularly, post-cracking behaviour, as one of the major sources of non-linearity, is the most important task of deformational analysis.

Recently a new constitutive relationship for cracked tensile concrete in flexure has been proposed by the first author [1] for short-term deformational analysis of flexural reinforced concrete members. It is based on a simplified averaging procedure (more convenient for finite element formulation), the smeared representation of cracked concrete, which implies that cracks are not discrete but continuously distributed. Cracking and bond effects as well as shrinkage effects are taken into account in an integrated manner by a modified stress-strain diagram for concrete in tension. The proposed relationship has been developed on a basis of a number of average stress-strain curves for tensile concrete obtained from beam tests re ported in literature.

Accuracy of the proposed constitutive relationship has been investigated for moderately and highly reinforced experimental beams reported in literature for a wide range of concrete strengths $[2,3]$. These statistical investigations have shown that the proposed constitutive relationship assures good curvature/deflection predictions for flexural reinforced concrete members with moderate and high reinforcement ratios. Good accuracy has also been achieved for design code methods of different countries [4-6]. However, the analysis [2] has also shown that lightly reinforced beams is an extreme case of bending analysis, because the stress-strain state as well as curvatures and deflections are significantly influenced by effects of cracked tensile concrete. Since tensile strength is a highly dispersed value, it is difficult to predict deflections accurately, particularly at loads just above the cracking loads.

This paper investigates the availability of the proposed constitutive relationship [1] for calculation of short-term deflections of flexural lightly reinforced concrete members. For that purpose, the proposed stressstrain relationship was incorporated into a simple iterative technique of deformational analysis based on classical expressions of strength of materials extended to layered approach. By this technique, deflections have been calculated for 33 experimental lightly reinforced concrete beams reported by Figarovskij [7]. Also statistical comparison with deflection estimates of three well known analytical methods as well as with predictions made for three constitutive relationships for cracked tensile concrete has been carried out.

\section{Calculation methods and constitutive relationships employed for comparative deflection analysis}

In this section, calculation methods and constitutive relationships employed for comparative deflection analysis of flexural reinforced concrete members are briefly described. The first three methods chosen for comparison are the following code methods described in [2]:

1) American Code (ACI Committee 318 [4]),

2) Eurocode EC2 [5],

3) Russian (old Soviet) Code (SNiP 2.03.01-84 [6]).

Although these methods are based on different analytical approaches, all of them proved to be accurate tools 
for deflection assessment of members with high and average reinforcement ratios $[2,3]$. It should be noted that these methods have quite a different level of complexity since the Russian Code method employs a great number of parameters and expressions whereas the $\mathrm{ACI}$ and $\mathrm{EC} 2$ methods are simple and include only basic parameters.

Another method, here called the layered method, is based on classical techniques of strength of materials extended to application of layered approach and full material diagrams. The iterative technique of the layered method is described in section 3 . Four different analyses by the layered method have been carried out assuming different stress-strain relationships (descending branches) for the cracked tensile concrete.

4) Vecchio and Collins in their modified compression field theory [8] proposed the following relationship based on experimental investigation of reinforced concrete panels subjected to pure shear:

$$
\begin{gathered}
\sigma_{t}=\frac{\sigma_{c r}}{1+\sqrt{200 \varepsilon_{t}}}, \\
\sigma_{c r}=0.33 \sqrt{f_{c}^{\prime}},[\mathrm{MPa}],
\end{gathered}
$$

where $\sigma_{t}$ and $\varepsilon_{t}$ are the stress and strain of tensile concrete, respectively; $\sigma_{c r}$ is the cracking stress of concrete; $f_{c}^{\prime}$ is the cylinder strength of concrete in compression.

5) Hsu in his unified theory of reinforced concrete [9] proposed the following relationship:

$$
\begin{gathered}
\sigma_{t}=\sigma_{c r}\left(\frac{\varepsilon_{c r}}{\varepsilon_{t}}\right)^{0.4}, \\
\sigma_{c r}=0.311 \sqrt{f_{c}^{\prime}},[\mathrm{MPa}] \\
\varepsilon_{c r}=0.00008,
\end{gathered}
$$

where $\varepsilon_{c r}$ is the cracking strain of concrete.

6) Prakhya and Morley [10] made an attempt to include several parameters affecting the tension stiffening into the stress-strain curve of tensile concrete for analysis of flexural members. On a basis of simplified assumptions and by using some experimental data they have applied an equation proposed by Carreira and Chu [11]

$$
\sigma_{t}=\frac{\beta_{t} f_{t}^{\prime}\left(\varepsilon_{t} / \varepsilon_{t}^{\prime}\right)}{\beta_{t}-1+\left(\varepsilon_{t} / \varepsilon_{t}^{\prime}\right)^{\beta_{t}}},
$$

by modifying the empirical factor $\beta_{t}$ :

$$
\beta_{t}=\left(\frac{100 A_{s}}{b\left(h-x_{n t}\right)}\right)^{0.366}\left(\frac{b\left(h-x_{n t}\right)}{n \pi c d_{b}}\right)^{0.344}\left(\frac{c}{s}\right)^{0.146},
$$

where $A_{s}$ is the cross-section area of tensile reinforcement; $b$ is the width; $h$ is the total depth; $c$ is the clear cover to the reinforcement; $d_{b}$ is the reinforcement bar diameter; $n$ is the number of bars; $s$ is the reinforcing spacing, and $x_{n t}$ is the neutral axis depth neglecting tension in the concrete.

7) Kaklauskas [1] proposed the following stress-strain relationship (see Fig 1) depending on reinforcement ratio $p$ :

$$
\sigma_{t}=0.625 \sigma_{c r}\left(1-\frac{\overline{\varepsilon_{t}}}{\beta}-\frac{1+0.6 \beta}{\beta \overline{\varepsilon_{t}}}\right),
$$

where

$$
\begin{gathered}
\overline{\varepsilon_{t}}=\frac{\varepsilon_{t}}{\varepsilon_{c r}}, \\
\beta=32.8-27.6 p+7.12 p^{2}, \\
(\beta=5, \text { if } p \geq 2 \%) .
\end{gathered}
$$

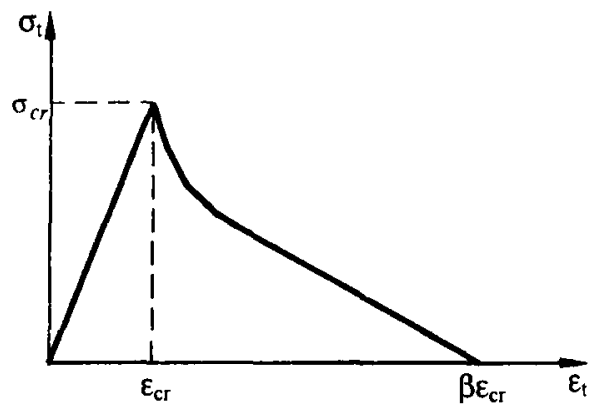

Fig 1. Stress-strain relationship for tensile concrete in flexure

If values of concrete tensile strength, $\sigma_{c r}$, and modulus of elasticity, $E_{c}$, are not available, they can be determined from the following empirical formulae:

$$
\begin{gathered}
\sigma_{c r}=0.23 \sqrt[3]{R_{15}^{2}}[\mathrm{MPa}], \\
E_{c}=\frac{5.5 R_{15}}{27+R_{15}} \times 10^{4}[\mathrm{MPa}],
\end{gathered}
$$

where $R_{15}$ is $150 \mathrm{~mm}$ cube compression strength.

For beams reinforced with plain bars, it is recommended to multiply $\beta$ by factor 0.7 . 


\section{Deflection calculation based on the layered approach}

The calculation is based on classical techniques of strength of materials extended to application of layered approach and full material diagrams. It is based on the following approaches and assumptions: 1) linear distribution of strain within the depth of the beam section; 2) assumption of perfect bond between concrete and reinforcement; 3) smeared crack approach; 4) layered approach; 5) stress-strain material relationships assumed to be constant for different layers of the same material.

Consider a non-prestressed doubly reinforced concrete member of I-section (Fig 2, a) subjected to bending only. The beam's cross-section is divided into a number of horizontal layers (Fig 2, b) corresponding to either concrete or reinforcement. Thickness of the reinforcement layer is taken from the condition of the equivalent area. Each layer may have different material properties assumed to be constant over the layer thickness.

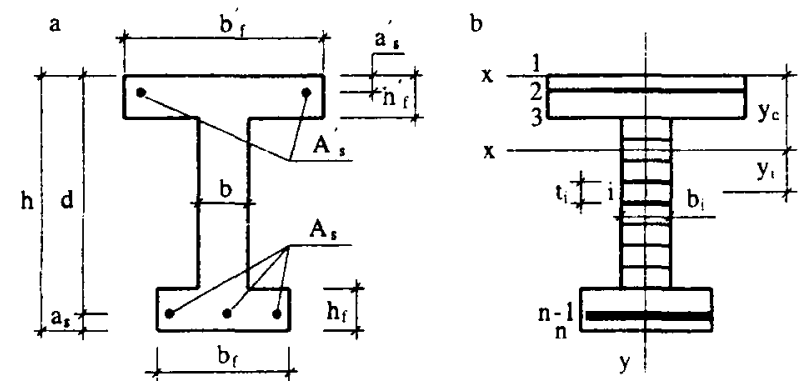

Fig 2. A cross-section of doubly reinforced concrete member in layered approach

For reinforcement material idealisation, a bilinear, trilinear or more complex stress-strain relationship can be adopted. For modelling the behaviour of the tensile concrete, the stress-strain relationships presented in the previous section have been employed. The stress-strain relationship shown in Fig 3 has been assumed for the compressive concrete where the ascending part has been taken according to the well-known expression:

$$
\sigma_{c}=f_{c}^{\prime}\left[2 \frac{\varepsilon_{c}}{\varepsilon_{0}}-\left(\frac{\varepsilon_{c}}{\varepsilon_{0}}\right)^{2}\right],\left(\varepsilon_{0}=2 f_{c}^{\prime} / E_{c}\right),
$$

where $\sigma_{c}$ and $\varepsilon_{c}$ are the stress and strain respectively of the compressive concrete; $f_{c}^{\prime}$ and $\varepsilon_{0}$ are the maximum compressive stress and the corresponding strain for standard cylinder (prism) test.

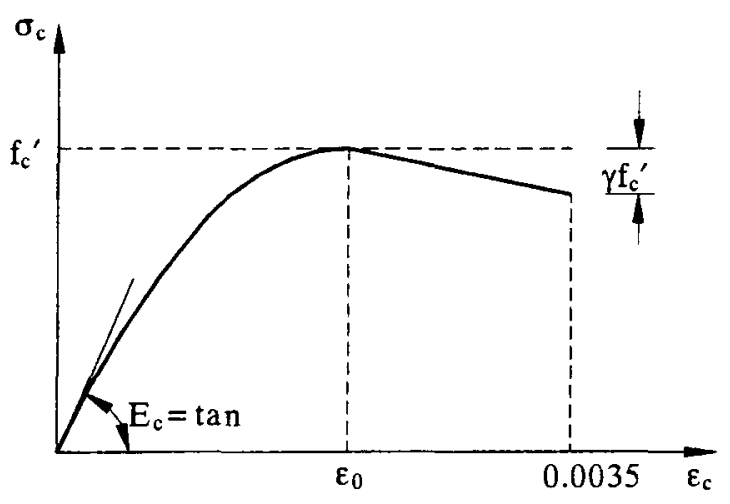

Fig 3. Stress-strain relationship for compressive concrete

A computer program has been developed for assessment of average stress and strain state at any point of a beam as well as for calculation of curvatures and deflections. For a given external moment, the computation is performed in iterations by the following steps:

1. In the first iteration, elastic material properties are assumed for all the layers.

2. Geometrical characteristics are calculated for the transformed cross-section, see Fig 1, b:

$$
\begin{gathered}
A_{t r}=\sum_{i=1}^{n} b_{i} t_{i} \frac{E_{i}}{E_{c}}, \\
S_{x 1, t r}=\sum_{i=1}^{n} b_{i} t_{i} d_{i} \frac{E_{i}}{E_{c}}, \\
y_{c}=\frac{S_{x 1, t r}}{A_{t r}}, \\
I_{x, t r}=\sum_{i=1}^{n}\left(\frac{b_{i} t_{i}^{3}}{12}+b_{i} t_{i} y^{2}\right) \frac{E_{i}}{E_{c}},
\end{gathered}
$$

where $A_{t r}$ and $S_{x 1, t r}$ are respectively the area and the first moment of area of the transformed section in respect of axis $x_{1} ; y_{c}$ is the coordinate of the centroid of the transformed section in respect to axis $x_{1} ; l_{x, t r}$ is the moment of inertia of the transformed section in respect of axis $x ; b_{i}$ and $t_{i}$ are respectively the width and thickness of $i$-th layer $(i=1,2 \ldots n)$; and $y_{i}$ is the coordinate of $i$-th layer in respect of the centroid of the transformed cross-section (axis $x$ ).

3. Curvature of the section is calculated from the expression:

$$
\kappa=\frac{M}{E_{c} I_{x, t r}}
$$


4. Longitudinal strain at every layer $i$ is taken as

$$
\varepsilon_{i}=\kappa y_{i} .
$$

5. For the assumed material diagrams (Figs 1 and 3), stress $\sigma_{i}$ corresponding to strain $\varepsilon_{i}$ is obtained. A secant deformation modulus $\bar{E}_{i}=\sigma_{i} / \varepsilon_{i}$ is determined.

6. Values of the obtained secant deformation modulus $\overline{E_{i}}$ for every layer are compared with the previously assumed or computed ones. If the agreement is not within the assumed error limits, a new iteration is started from step 2 .

7. After convergation of the deformation modulus $\bar{E}_{i}$ for all the layers, final values of strains, stresses and curvature are assessed. For deflection calculation which is performed by Mohr's integral technique, analogous computations are carried out for other sections of the beam.

\section{Figarovskij test results in flexure}

Figarovskij [7] conducted experiments on lightly reinforced concrete beams with different reinforcement ratios using both plain and deformed bars. The experimental program was devoted to investigation of shortterm and long-term deformations and deflections of reinforced concrete beams. The beams were nominally $3.2 \mathrm{~m}$ long and were tested under a four-point loading system which gave a constant moment zone and two shear spans of $1.0 \mathrm{~m}$ each. Data on $100 \mathrm{~mm}$ concrete cube strength, $R_{10}$, as well as diameter and number of tensile reinforcement bars and reinforcement ratio, $p$, for each of the specimen are given in Table 1. The experimental specimens were divided into four series. Beams of the first series were reinforced with plain bars and the remaining beams with the deformed bars. The beams of the first three series had a rectangular section, nominally 250 $\mathrm{mm}$ in height and $180 \mathrm{~mm}$ in width. Beams of the fourth series had T-section with the flange in the tension zone. The nominal width and height of the flange was 180 and $45 \mathrm{~mm}$ respectively. The beams of the first and third series were reinforced with top reinforcement comprising two $6 \mathrm{~mm}$ bars located at $15 \mathrm{~mm}$ from the top surface. Stirrups in the shear spans were provided for all the beams.

Tests of the beams were terminated prior to the yielding of reinforcement and the experimental results were presented in terms of moment-deflection, $(M-f)$, diagrams for each of the specimen [7].
Table 1. Main characteristics of specimens (Figarovskij [7])

\begin{tabular}{|c|c|c|c|c|}
\hline No & Name & $\begin{array}{c}R_{10} \\
{[\mathrm{MPa}]}\end{array}$ & $\begin{array}{c}\text { No of bars } \\
\text { and diame- } \\
\text { ter [mm] }\end{array}$ & $\begin{array}{c}p \\
{[\%]}\end{array}$ \\
\hline \multicolumn{5}{|c|}{ Series I } \\
\hline 1 & $\mathrm{P} 3-1 \mathrm{Kk}$ & 20.0 & $5 \times 8$ & 0.62 \\
\hline 2 & P3-2Kd & 30.5 & $5 \times 8$ & 0.62 \\
\hline 3 & P2-2Kd & 21.0 & $4 \times 8$ & 0.49 \\
\hline 4 & P2-1Kk & 20.0 & $4 \times 8$ & 0.50 \\
\hline 5 & Pl-1Kk & 28.5 & $3 \times 8$ & 0.37 \\
\hline 6 & $\mathrm{Pl} 1-2 \mathrm{Kk}$ & 28.5 & $3 \times 8$ & 0.37 \\
\hline \multicolumn{5}{|c|}{ Series II } \\
\hline 7 & $\mathrm{P} 2-3^{\prime}$ & 36.0 & $6 \times 10$ & 1.01 \\
\hline 8 & $\mathrm{P} 2-3$ & 36.0 & $6 \times 10$ & 0.99 \\
\hline 9 & P1-3 & 36.0 & $3 \times 10$ & 0.51 \\
\hline 10 & $\mathrm{P} 2-2$ & 15.5 & $6 \times 10$ & 1.04 \\
\hline 11 & $\mathrm{P} 2-1$ & 10.5 & $6 \times 10$ & 1.03 \\
\hline 12 & P1-2 & 15.5 & $3 \times 10$ & 0.50 \\
\hline 13 & $\mathrm{P} 1-1$ & 10.5 & $3 \times 10$ & 0.51 \\
\hline 14 & $P^{\prime} 1-1$ & 10.5 & $3 \times 10$ & 0.51 \\
\hline \multicolumn{5}{|c|}{ Series III } \\
\hline 15 & P3-2Pd & 31.5 & $3 \times 12$ & 0.88 \\
\hline 16 & P3-1Pd & 31.5 & $3 \times 12$ & 0.88 \\
\hline 17 & $\mathrm{P} 2-2 \mathrm{Pk}$ & 36.0 & $5 \times 7.5$ & 0.47 \\
\hline 18 & P3-1Pk & 21.0 & $7 \times 7$ & 0.57 \\
\hline 19 & P2-2Pd & 34.0 & $5 \times 7.5$ & 0.47 \\
\hline 20 & P2-IPk & 22.0 & $5 \times 7$ & 0.42 \\
\hline 21 & P1-2Pk & 21.0 & $3 \times 7$ & 0.25 \\
\hline 22 & P1-1Pk & 22.0 & $3 \times 7$ & 0.25 \\
\hline 23 & P0-2Pk & 34.0 & $2 \times 7$ & 0.16 \\
\hline 24 & P0-1Pk & 34.0 & $2 \times 7$ & 0.17 \\
\hline \multicolumn{5}{|c|}{ Series IV } \\
\hline 25 & T3.2Pd & 34.0 & $7 \times 7$ & 1.26 \\
\hline 26 & T3-1Pd & 34.0 & $7 \times 7$ & 1.20 \\
\hline 27 & $\mathrm{~T} 2-1 \mathrm{Pd}$ & 30.5 & $5 \times 7.5$ & 0.90 \\
\hline 28 & T2-2Pd & 30.5 & $5 \times 7.5$ & 0.86 \\
\hline 29 & $\mathrm{~T} 1.2 \mathrm{Pk}$ & 35.0 & $3 \times 7$ & 0.44 \\
\hline 30 & T1-1Pk & 35.0 & $3 \times 7$ & 0.44 \\
\hline 31 & T0-1Pk & 36.0 & $2 \times 7$ & 0.30 \\
\hline 32 & $\mathrm{~T} 1-2 \mathrm{Pd}$ & 22.0 & $3 \times 7$ & 0.47 \\
\hline 33 & T1-1Pd & 22.0 & $3 \times 7$ & 0.44 \\
\hline
\end{tabular}

\section{Comparison of deflections assessed by different methods with test results}

This section compares mid-span deflections assessed by different code methods and the layered method using different constitutive relationships for cracked tensile concrete (see section 2) with the test data of 33 beams characterised in section 4 (Table 1). This investigation disregards shear effects. 
Two different analyses have been carried out. In the first analysis, deflections were calculated at five moment levels, ie $0.4,0.55,0.6,0.7$ and 0.8 of $M_{y}$ which is the yielding moment. The moments smaller than the cracking moment were excluded from the analysis. However, for some of the beams [7] only one or two experimental deflection points corresponding to the above indicated moment levels were available. This was due to two reasons: 1) tests of many beams, particularly those later on subjected to long-term loading, were terminated at early stages; 2) for some beams, particularly those with very small reinforcement ratios, the experimental cracking moment, $M_{c r, \exp }$, exceeded $0.4 M_{y}$. Therefore, the second analysis has been carried out with deflections calculated at five moment levels equally spaced between moments $1.1 M_{c r, \exp }$ and $M_{\max , \exp }$ where $M_{\max , \exp }$ is the maximum moment reached in the experiment. The lower limit assured comparison of deflections to be performed for the cracked stage.

Accuracy of predictions made by each method has been assessed using basic statistical parameters such as mean value and standard deviation calculated for relative deflections $f_{t h} / f_{\text {exp }}$. Results of the two analyses are presented in Table 2.

In the first analysis, the most accurate predictions in terms of standard deviation (13.6\%) has been achieved by the layered method using the stress-strain relationship for tensile concrete (5) proposed by Kaklauskas. The mean $f_{t h} / f_{\text {exp }}$ value being below unity refers to non-assessed deflections due to shear. Deflections caused by shear are relatively larger for lightly reinforced and thin-walled members what is the case for the present analysis. Accurate predictions were made by the Russian Code and $\mathrm{ACI}$ methods yielding standard deviations of 0.183 and $0.186 \%$ respectively. Similar value $(19.4 \%)$ was obtained for the layered method using the stress-strain relationship of tensile concrete proposed by Vecchio and Collins (1), however it yielded rather conservative mean value of $f_{t h} / f_{\text {exp }}$. The remaining three estimates (EC2, Hsu and Prakhya-Morley) gave rather poor results. The shocking value of $36.2 \%$ for the EC2 method can be explained by inaccuracies of the deflection estimates made at loads just above the cracking loads. The EC2 method underestimates the cracking moment and often significantly overestimates the corresponding deflection in some cases yielding an error of over $100 \%$. Also surprising is poor prediction by the layered method using the multiparameter constitutive relationship of Prakhya-Morley $(3,4)$.

Although the order of the methods with the best predictions in the second analysis was quite similar to that of the first analysis (Table 2), some methods/constitutive relationships (EC2, Hsu and Prakhya-Morley) yielded improved results while the other (Kaklauskas, ACI and the Russian Code) led to reduced accuracy.

For visualisation purposes, relative deflections versus relative moments are presented graphically in Figs 4 to 7 for the ACI, EC2, Russian Code methods and the layered method using Kaklauskas constitutive relationship, respectively. Data points in Figs 4 to 7 corresponding to different series are marked differently.

It must be noted that calculation results for beams P0-2Pk and P0-1Pk of the third series (Table 1) were not included neither into Table 2 nor into Figs 4 to 7 , because deflection assessments by all the methods were extremely inaccurate. This was due to the fact that the beams had a very low reinforcement ratio ( $p=0.16 \%$ ) and their moment-deflection diagrams above the cracking moment were approaching the horizontal line, ie large deflections increments corresponded to small moment increments.

Table 2. Statistical parameters for relative deflections, $f_{t h} / f_{\text {exp }}$, estimated by different methods (constitutive relationships) for total data [7]

\begin{tabular}{|c|c|c|c|c|c|c|c|c|}
\hline \multirow[t]{2}{*}{$\begin{array}{l}\text { Analysis } \\
\text { No }\end{array}$} & \multirow[t]{2}{*}{$\begin{array}{c}\text { Statistica } \\
\text { parameter }\end{array}$} & \multicolumn{3}{|c|}{ Code method } & \multicolumn{4}{|c|}{$\begin{array}{l}\text { Layered method using the constitutive relationship for } \\
\text { tensile concrete }\end{array}$} \\
\hline & & $\mathrm{ACI}$ & $\mathrm{EC} 2$ & SNiP & $\begin{array}{l}\text { Vecchio - } \\
\text { Collins }\end{array}$ & Hsu & $\begin{array}{l}\text { Prakhya- } \\
\text { Morley }\end{array}$ & Kaklauskas \\
\hline \multirow[t]{2}{*}{1} & Mean & 1.024 & 1.189 & 0.972 & 0.885 & 1.106 & 1.092 & 0.924 \\
\hline & Standard & 0.186 & 0.362 & 0.183 & 0.194 & 0.374 & 0.366 & 0.136 \\
\hline \multirow[t]{2}{*}{2} & Mean & 1.115 & 1.230 & 1.003 & 0.927 & 1.125 & 1.148 & 0.957 \\
\hline & Standard & 0.266 & 0.320 & 0.204 & 0.193 & 0.281 & 0.342 & 0.168 \\
\hline
\end{tabular}


It is very difficult to predict accurately deflections for beams which yielding moment just slightly exceeds the cracking moment. It can be also concluded that greater discrepancies between the predicted and experimental deflections corresponded to smaller loads, particularly those just above the cracking load (see Figs 4-7).

For fair treatment of the results presented in Table 2, the following must be said. Experimental data of Figarovskij [7] were used in developing the Russian Code method [6] and the moment-curvature diagrams of the

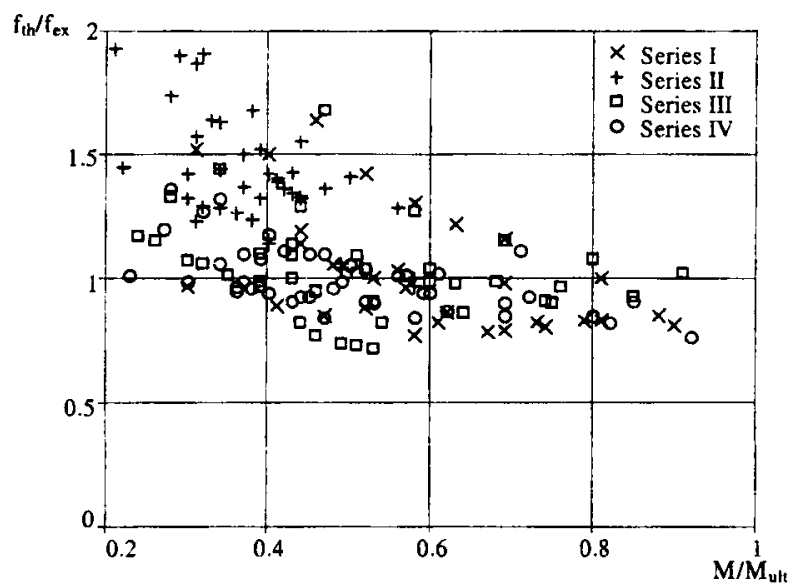

Fig 4. ACI method [4] predictions: relative deflections versus relative moments

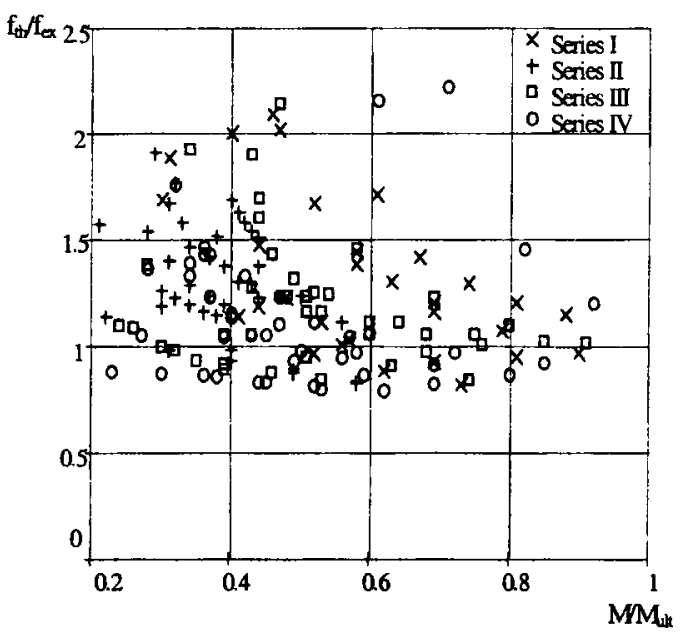

Fig 5. EC2 method [5] predictions: relative deflections versus relative moments third and partly of the first series were employed for developing the material model of tensile concrete proposed by Kaklauskas [1]. Besides, these two methods use similar empirical material characteristics for concrete (compressive and tensile strength and modulus of elasticity) to those used by Figarovskij. On the other hand, statistical analysis performed for the experimental data excluding the data of the first and third series (Table 3 ) gave very similar results for Kaklauskas constitutive relationship to those of the total analysis (Table 2).

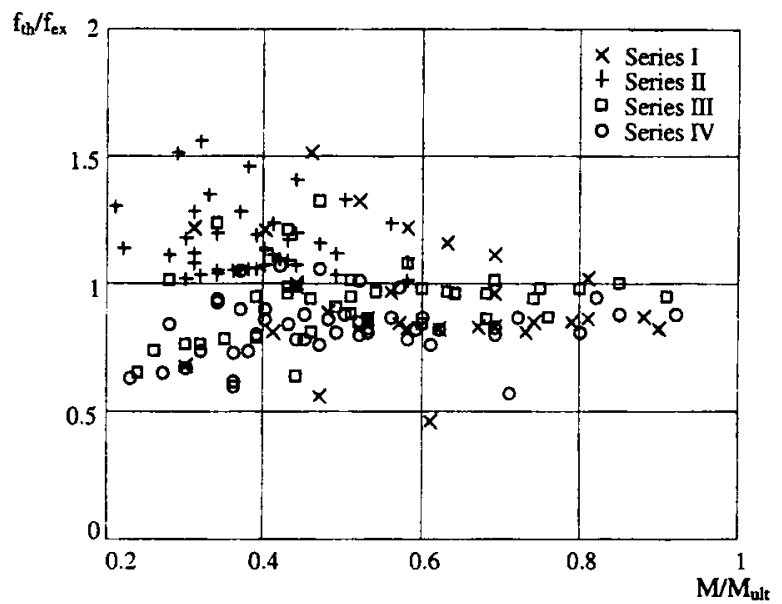

Fig 6. Russian Code method [6] predictions: relative deflections versus relative moments

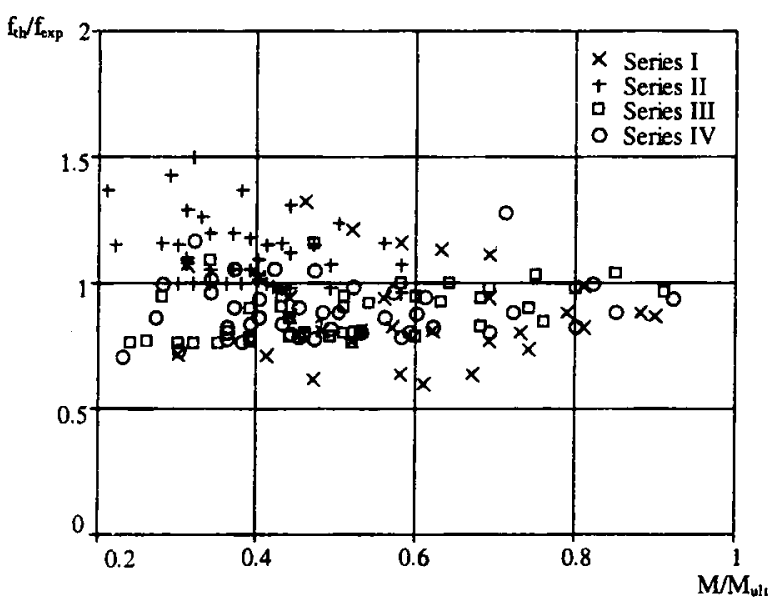

Fig 7. Layered code method predictions using the constitutive relationship for tensile concrete proposed by Kaklauskas [1]: relative deflections versus relative moments 
Table 3. Statistical parameters for relative deflections, $f_{t h} / f_{\text {exp }}$, estimated by different methods (constitutive relationships) for data of beam series II and IV [7]

\begin{tabular}{|c|c|c|c|c|c|c|c|c|}
\hline \multirow[t]{2}{*}{$\begin{array}{l}\text { Analysis } \\
\text { No }\end{array}$} & \multirow[t]{2}{*}{$\begin{array}{r}\text { Statistica } \\
\text { parameter }\end{array}$} & \multicolumn{3}{|c|}{ Code method } & \multicolumn{4}{|c|}{$\begin{array}{l}\text { Layered method using the constitutive relationship for } \\
\text { tensile concrete }\end{array}$} \\
\hline & & $\mathrm{ACI}$ & $\mathrm{EC} 2$ & SNiP & $\begin{array}{l}\text { Vecchio - } \\
\text { Collins }\end{array}$ & Hsu & $\begin{array}{l}\text { Prakhya- } \\
\text { Morley }\end{array}$ & Kaklauskas \\
\hline \multirow[t]{2}{*}{1} & Mean & 1.046 & 1.147 & 1.030 & 0.959 & 1.197 & 1.267 & 0.941 \\
\hline & Standard & 0.191 & 0.359 & 0.185 & 0.219 & 0.486 & 0.453 & 0.139 \\
\hline \multirow[t]{2}{*}{2} & Mean & 1.190 & 1.221 & 1.067 & 1.007 & 1.198 & 1.311 & 1.003 \\
\hline & Standard & 0.281 & 0.307 & 0.202 & 0.188 & 0.309 & 0.359 & 0.169 \\
\hline
\end{tabular}

\section{Concluding remarks}

Accuracy of the proposed constitutive relationship for tensile concrete in flexure [Eq (5)] has been investigated by means of deflection estimation for 33 lightly reinforced experimental RC beams [7]. Comparison with the experimental deflections at five load levels and with estimates of six other methods/constitutive relations has been performed.

The comparison has shown (Table 2) that the most accurate predictions in terms of standard deviation calculated for relative deflections $f_{t h} / f_{\exp }$ has been achieved $(13.6 \%)$ by the layered method using the stress-strain relationship for tensile concrete under investigation [(Eq 5)]. Accurate predictions were made by the Russian Code and $\mathrm{ACI}$ methods yielding standard deviations of 0.183 and $0.186 \%$ respectively. Similar value $(19.4 \%)$ was obtained for the layered method using the stress-strain relationship of tensile concrete proposed by Vecchio and Collins, however it yielded rather conservative mean value of $f_{t h} / f_{\text {exp }}$. The remaining three estimates (EC2, Hsu and Prakhya-Morley) gave rather poor results.

\section{References}

1. G. Kaklauskas. A New Stress-Strain Relationship for Cracked Tensile Concrete in Flexure / Statyba, Vol V, No 6. Vilnius: Technika, 1999, p. 349-356.

2. G. Kaklauskas, D. Bacinskas and R. Šimkus. Deflection Estimates of Reinforced Concrete Beams by Different Methods // Statyba, Vol V, No 4. Vilnius: Technika, 1999, p. 258-264.

3. G. Kaklauskas and M. Hallgren. Curvature Analysis of High Strength Concrete Beams // Statyba, Vol V, No 6. Vilnius: Technika, 1999, p. 357-363.

4. ACI Committee 318. Building Code Requirements for Reinforced Concrete and Commentary (ACI 318-89/ACl 318R-89). Detroit: American Concrete Institute (ACI), 1989. $353 \mathrm{p}$.
5. ENV 1992-1-1. Eurocode 2 (EC2): Design of Concrete Structures - Part 1: General rules and rules for buildings. Brussels, $1992.114 \mathrm{p}$.

6. СНиП 2.03.01-84*. Бетонњые и железобетонные конструкщии М.: Госстрой СССР, $1989.80 \mathrm{c}$.

7. В. В. Фигаровский. Экспериментальное исследование жесткости и трешиностойкости железобетонных изгибаемых элементов при кратковременном и длительном действии нагрузок: Дис. ... канд. техн. наук. Москва, 1962.

8. F. J. Vecchio and M. P. Collins. The Modified Compression Field Theory for Reinforced Concrete Elements Subjected to Shear // J. Amer. Concrete Inst., 83(2), 1986, p. 219-231.

9. T. T. C Hsu. Unified Theory of Reinforced Concrete, CRC Press, Inc., 1993. 336 p.

10. G. K. V. Prakhya and C. T. Morley. Tension Stiffening and Moment-Curvature Relations for Reinforced Concrete Elements // ACI Journal, 87(5), 1990, p. 597-605.

11. D. J. Careira and K. -H. Chu. Stress-Strain Relationship of Reinforced Concrete in Tension // ACI Journal, 83(1), 1986, p. 21-28.

Iteikta 19991210

\section{MAŽAI ARMUOTŲ GELŽBETONINIỤ SIJU ILINKIỤ VERTINIMAS PAGAL IVAIRIUS MEDŽLAGU MODE- LIUS IR METODUS}

\section{G. Kaklauskas, D. Baxinskas}

\section{Santrauka}

Darbe tiriamas pirmojo autoriaus pasiūlytos [1] supleišèjusio tempiamo betono ittempiu-deformaciju priklausomybes (5) tikslumas, vertinant mažai armuotų lenkiamujų gelžbetoninių elementu deformatyvumą. Tuo tikslu 33 mažai ir vidutiniškai armuotoms sijoms (1 lent.), kurias trumpalaike apkrova (dviem koncentruotomis jègomis) išbandè Figarovskis [7], buvo apskaiciuoti ilinkiai. Jie buvo apskaiciuoti ir trimis normy metodais - amerikieciu [4], Euronormu [5] bei Lietuvoje galiojancių normu [6]. Be to, ilinkiai buvo apskaiciuoti sluoksniu metodu, taikant keturias tempiamo betono itempiu-deformaciju priklausomybes: Vecchio ir Collinso (1) [8], Hsu (2) [9], Prakhya ir Morley $(3,4)[10]$ bei pirmojo autoriaus.

Ilinkiai buvo apskaiciuoti dviem apkrovu atvejams. Pirmuoju atveju jie buvo nustatyti tokiems penkiems apkrovos lygiams: $0.4 ; 0,55 ; 0,6 ; 0,7$ ir $0.8 M_{y}$, kur $M_{y}$ yra apskai- 
ciuotas lenkimo momentas, atitinkantis armatūros takumo ribą. Deja, ne visoms sijoms buvo nustatyti eksperimentiniai jlinkiai tuose apkrovos lygiuose. Todèl antruoju atveju ilinkiai buvo apskaiciuoti penkiuose tolygiai išdèstytuose apkrovos lygiuose, atitinkanciuose lenkimo momento intervalą tarp $1,1 M_{c r, \exp }$ ir $M_{\text {max,exp }}$, kur $M_{c r, \exp }$ yra eksperimentinis pleiš́jimo momentas, o $M_{\text {max, } \exp }$ yra maksimalus eksperimente pasiektas lenkimo momentas.

Vertinant tiksluma kiekvienam skaičiavimo metodui buvo nustatyti tokie svarbiausi statistiniai dydžiai kaip vidurkis bei vidutinis kvadratinis nuokrypis. Sie statistiniai parametrai gauti santykiniams ilinkiams $f_{\text {th }} / f_{\text {exp }}$, kur $f_{\text {th }}$ yra apskaixiuotas, o $f_{\text {exp }}$ - eksperimentinis ilinkis.

Skaiciavimo rezultatai (2 lent.) parodè, kad pirmajam apkrovų atvejui mažiausia vidutine kvadratinè paklaida $(13,6 \%)$ gauta sluoksnių metodu taikant pirmojo autoriaus pasiūlyta tempiamo betono priklausomybę. Mažesnè už vieneta vidurkio reikšmé rodo, kad turètu būti ivertintos ir šlyties deformacijos. Šlyties įtaka didesnè mažai armuotoms plonasienèms sijoms.

Gana tiksliai siju ilinkiai buvo apskaiciuoti ir Lietuvoje galiojančių bei amerikiečị normų metodais (vidutinis kvadratinis nuokrypis atitinkamai 18,3 ir $18,6 \%$ ). Sluoksniu metodui, taikant Vecchio ir Collinso tempiamo betono priklausomybe, gautas $19,4 \%$ nuokrypis. Likusiems trims metodams/medžiagu priklausomybèms gautos didokos paklaidos (2 lent.). Skaiciuojant antrajam apkrovy reikśmiu atvejui, „tiksliausiu“ metodų/medžiagu modelių seka (2 lent.) iš esmès nepakito. Vaizdumo dèlei pateiktos santykiniu ilinkių-momentų priklausomybès trims normu metodams (4-6 pav.) bei sluoksniu metodui, taikant pirmojo autoriaus pasiūlytaji tempiamo betono modeli
(7 pav.). Iš siu priklausomybiu matyti, kad visiems metodams rezultatų sklaida mažeja, didejant apkrovai. Tai nesunkiai gali būti paaiškinta mažèjancia supleišejusio tempiamo betono ịtaka sijy deformacijoms.

Būtina pažymèti, kad Figarovskio eksperimentinį siju duomenys (1 lent.) buvo panaudoti, kuriant Lietuvoje galiojanciu normy metoda [6], o trečiosios bei is dalies pirmosios siju seriju duomenys - ir išvedant (5) priklausomybę. Be to, taikant abu šiuos metodus betono charakteristikoms (stipnumo tempiant ir gniuždant bei tamprumo moduliui) nustatyti naudotos empirinès formules, panasios i taikytas eksperimenty autoriaus. Kita vertus, atlikus apskaiciavimus, kuriuose nebuvo vertinami pirmosios ir trexiosios seriju duomenys, sluoksniu metodui ((5) priklausomybè) gauti labai panašūs rezultatai (3 lent.).

Gintaris KAKLAUSKAS. PhD, Senior Researcher and Associate Professor. Dept of Reinforced Concrete Structures. Vilnius Gediminas Technical University (VGTU), Sauletekio al. 11, LT-2040 Vilnius, Lithuania.

Graduate of Vilnius Civil Engineering Institute (presently VGTU) (1982, civil engineer). PhD (1990). Research visits: Aalborg University (Denmark, 1991), University of Glamorgan (UK, 1994/1995/1998), University of Illinois, UrbanaChampaign (USA, 1996). Author and co-author of 2 monographs, 1 invention and a number of papers. Research interests: development of constitutive relationships for concrete and numerical simulation of reinforced concrete structures.

Darius BAČINSKAS. PhD student. Dept of Reinforced Concrete Structures. Vilnius Gediminas Technical University (VGTU), Sauletekio al. 11, LT-2040 Vilnius, Lithuania.

MSc (1997, civil engineer) at VGTU. Co-author of 3 research papers. Research interests: deformation of reinforced concrete structures. 